DOI: 10.20472/IAC.2019.049.027

\author{
KAARINA MÄÄTTÄ \\ University of Lapland, Finland \\ MARJU MÄÄTTÄ \\ University of Lapland, Finland
}

\title{
LOVE AS A KEY ELEMENT TO WELLBEING
}

\begin{abstract}
:
This presentation is based on the new scientific book Love Around Us - The Role of Love in Education, Parenting and Romantic Relationships (Kaarina Määttä \& Satu Uusiautti, eds.) published by Peter Lang in 2018, and also the previous book Many Faces of Love (Kaarina Määttä \& Satu Uusiautti, authors), published by Sense Publishers.
\end{abstract}

In the presentation it will be discussed research on love as a key element of health, wellbeing and positive human development. People live in a network of relationships and their ability to build and maintain realationships is an important strength. Love has many definitions and also many forms and faces. The presentation provides a comprehensive analysis on love in various areas of human beings' life - the emergence and manifestation of romantic love in various phases of life, love in education, love for work, for fellow humans - and in relation to other phenomena, such as friendship, play, and creativity.

When dissecting love along the course of life, parental love and also grandparental love secures children's well-being and teachers' pedagogical love trusts in pupils' learning. The first taste of falling in love can manifest itself in the form of the sweet poison of love and still is quite far from actual love. The ability to love is an important, yet difficult, skill. There are numerous theories that explain the phases of long-lasting marriages and divorces, too. Nevertheless, love does not retire and the fascination of love does not fade, not even in senior age. Other topical phenomena of love are, for example, love for work and the successful combination of work and family.

Love in its whole gamut is connected to human wellbeing and development in different areas and phases of human life. Love, as its best, is manifested by the endeavor to make things develop, grow, and come forward, whether love falls on other people, art, science, ideas, or nature. A world where it is safe to love is a world where it is safe to live. The presentation concentrates on the best sides of love and I conclude that love, in its various forms, makes the best health insurance.

\section{Keywords:}

love, wellbeing, positive human development

JEL Classification: 100, 129, 131 